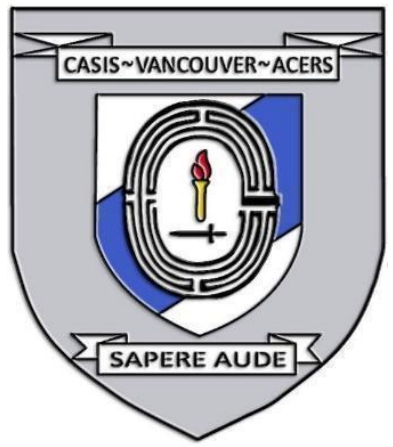

\title{
EXTREMIST PROPOGANDA AND THE 'POLITICS OF THE INTERNET'
}

Date: November $25^{\text {th }}, 2020$

Disclaimer: This briefing note contains the encapsulation of views presented by the speaker and does not exclusively represent the views of the Canadian Association for Security and Intelligence Studies.

\section{KEY EVENTS}

On November 25 ${ }^{\text {th }}$, 2020, Professor Julian Richards presented Extremist Propaganda and the 'Politics of the Internet' at the 2020 CASIS West Coast Security Conference. The presentation was followed by a question and answer period with other speakers. The key points of discussion focused on the effectiveness of internet use by extremist groups to expand their networks and spread disinformation.

\section{NATURE OF DISCUSSION}

\section{Presentation}

Professor Julian Richards discussed how the internet is used as a political space by extremists and Violent Transnational Social Movements (VTSM). He also examined the effectiveness of spreading disinformation during the 2016 Brexit referendum and the 2016 US presidential election.

\section{Question period}

The speaker considered alternative ways in which minority opinions can be expressed and heard by a democratic government to minimize escalation into extremist alternatives.

\section{BACKGROUND}

\section{Presentation}

The internet allows for frequent, high-volume and widely propagated messaging that can be used to capitalize on the "power of the mob". Many extremist groups and VTSMs are becoming increasingly skilled at exploiting the internet to establish transnational connections and develop networks across geographic 
boundaries without a clearly defined leader. Organized crime networks appear to be adopting decentralized strategies similar to that of VTSMs.

Although the internet has facilitated the networking and expansion of extremist groups and social movements, research shows that their goal to spread disinformation and malicious content are less effective at swaying public opinion than previously thought. Research shows that recirculating fake news on Twitter and Facebook during the 2016 presidential election and Brexit referendum was a rare activity. Moreover, face to face peer group socialization was more effective in the radicalization of "jihadist foreign fighters" than social media.

The state maintains an advantage over extremist groups with respect to legislation, licensing, and intelligence activity; however, much more research about extremist actors and the effects of internet use to further their political agenda is required.

\section{Question period}

Minority opinions are often not heard through the normal democratic process. This only serves to amplify their grievances and make extremist alternatives more appealing. Those who do not feel their opinions are being considered use the internet to seek out like-minded others and share their grievances transnationally. Making it easier for them to organize and mobilize into violent action. Grassroots movements and mechanisms would allow political parties and governments to work with diverse focus groups to gain a better understanding of minority opinions when developing public policy. Democratic institutions need to make a genuine effort to ensure minority opinions are heard and their grievances are addressed to minimize the transition to extreme alternatives.

\section{KEY POINTS OF DISCUSSION}

\section{Presentation}

- The internet facilitates networking across geographic boundaries and the dissemination of misinformation to the general public.

- Contrary to mainstream thinking, the spreading of malicious content and disinformation by extremist actors is a rare activity and minimally effective in swaying public opinion.

- The state maintains an advantage over extremist groups with respect to legislation, licensing, and intelligence activity. 


\section{Question period}

- The failure of state actors to consider minority opinions can eventually lead to widespread expression of their grievances online to a transnational audience and to the adoption of extremist alternatives.

- Democratic institutions and governments can minimize this escalation by making an effort to consider minority opinions and address grievances at a grassroots level.

- With regards to spreading disinformation during the 2020 US presidential election, it is likely that only a small proportion of the total will spread disinformation and conspiracy theories, similar to the 2016 election.

\section{(ब) $\odot \Theta$}

EY NO NO This work is licensed under a Creative Commons AttributionNonCommercial-NoDerivatives 4.0 International License.

(C) (Julian Richards, 2021)

Published by the Journal of Intelligence, Conflict, and Warfare and Simon Fraser University

Available from: https://jicw.org/ 